\title{
Değirmendere (Trabzon) Havzası Kaynak Sularında Su-Kayaç Etkileşimi
}

\author{
Water-Rock Interaction of Springwater in the Değirmendere Basin (Trabzon-NE Turkey) \\ EIham TAHMASEBZADEH BASTAM, Fatma GÜLTEKIN \\ Karadeniz Teknik Üniversitesi, Jeoloji Mühendisliği Bölümü, TRABZON
}

Geliş (Received): 22 Ağustos (August) 2016 / Düzeltme (Revised): 21 Kasım (November) 2016 / Kabul (Accepted): 13 Aralık (December) 2016

\section{ÖZ}

Genel olarak volkanik kayaçların yüzeylendiği Değirmendere Havzası'nda litolojik olarak bazalt, altere bazalt, andezit, altere andezit, tüf, dasit, volkanik katkılı marn türü kayaçlar tespit edilmiştir. Havzada tektonik hatlarla ilişkili olarak karbondioksit ve çözünmüş madde miktarı yüksek çok sayıda su kaynağı bulunmaktadır. Bunlar arasında incelenen 4 kaynakta debilerin 46-158 ml/sn, pH'ın 5.32-6.99, özgül elektriksel iletkenlik değerlerinin (ÖEİ) $603-1899 \mu \mathrm{S} / \mathrm{cm}$, çözünmüş oksijenin (ÇO) $3.20-9.35 \mathrm{mg} / \mathrm{l}$ ve toplam çözünmüş madde miktarının (TÇK) 380-1230 mg/l arasında değiştiği belirlenmiştir. $\mathrm{Ca}-\mathrm{HCO}_{3}$ su tipinde olan kaynakların kimyasal gelişiminde silikat ayrışması, karbonat ayrışması ve iyon değişimi türü su-kayaç etkileşim süreçlerinin etkili olduğu belirlenmiştir. İyon değişimini açıklamak için hesaplanan negatif Chloro Alkaline Indices (CAI) değerleri ters değiş tokuş olduğunu göstermiştir. $\delta^{18} \mathrm{O}-\delta^{2} \mathrm{H}$ ilişkisine göre meteorik kökenli olan kaynak suları Doğu Karadeniz Meteorik Su Doğrusu üzerinde yer almaktadır. İzotop değerlerine göre genç ve sı̆̆ dolaşımlı yeraltı suyunu boşaltan kaynakların kimyasal bileşimleri yoğun ayrışmanın gözlendiği volkanik kayaçların üst kısımlarındaki hareket sırasında gelişmiştir. $\mathrm{Ba}, \mathrm{Sr}$ ve Zn elementleri kayaçlarda olduğu gibi kaynak sularında da yüksek değerlerdedir. Kaynak sularındaki $\mathrm{Br}(0.036-$ $0.070 \mathrm{mg} / \mathrm{l})$ ve $\mathrm{Cr}(0.0625 \mathrm{mg} / \mathrm{l})$ değerleri Doğal Mineralli Sular Hakkındaki Yönetmelik (2004)’te önerilen sınır değerleri aşmaktadır.

Anahtar Kelimeler: Değirmendere Havzası, Hidrokimya, Kaynak suyu, Su-kayaç etkileşimi, Trabzon.

\begin{abstract}
In general, the rock types; basalt, andesite, altered andesite, tuff, dacite, and marl intercalating with volcanics, have been identified lithologically in the Değirmendere Basin. In the basin, there are many springs with a high carbon dioxide content and total dissolved solids, all of which are related to tectonic lines. Of these, four springs have discharge rates, $\mathrm{pH}$, specific electrical conductivity (SEC) and total dissolved solids (TDS), respectively, 46$158 \mathrm{ml} / \mathrm{sec}, 5.32-6.99,603-1899 \mu \mathrm{S} / \mathrm{cm}$ and $380-1230 \mathrm{mg} / \mathrm{l}$. It is determined that silicate weathering, carbonate weathering and ion-exchange type water-rock interaction processes were effective on the chemical evaluation of the $\mathrm{Ca}-\mathrm{HCO}_{3}$ water type springs. The Chloro Alkaline Indices (CAI), which are calculated to explain the ion-exchange, indicated a reverse exchange. Based on $\delta^{18} O-\delta^{2} H$ correlation, the springs which have a meteoric origin lie on the Eastern Black Sea Metoric Water Line. According to the isotopic values, the chemical composition of the young and shallow circulating springs was developed during circulating to the upper parts of the volcanic rocks where an intense weathering was observed. The concentration of $\mathrm{Ba}, \mathrm{Sr}$ and $\mathrm{Zn}$ are high as in the rocks. $\mathrm{Br}(0.036-0.070 \mathrm{mg} / \mathrm{l})$ and $\mathrm{Cr}(0.062 \mathrm{mg} / \mathrm{l})$ values of the springs exceed the limit recommended in the Natural Mineral Water Regulation (2004).
\end{abstract}

Keywords: Değirmendere Basin, Hydrochemistry, Spring water, Water-rock interaction, Trabzon. 
Tahmasebzadeh Bastam, Gültekin

\section{GİRIŞ}

Yeraltı sularının doğal boşalımı olan kaynakların kimyasal bileşimleri, suyun içerisinden geçtiği kayaçların ve zeminlerin kimyasal bileşimine, jeokimyasal süreçlere, suyun jeolojik formasyonlardaki minerallerle karşılaşma sırasına bağlı olarak değişiklik gösterir (Freeze ve Cherry, 1979). Bu değişiklikler kayaçların kimyası ile yakından ilişkilidir. Sukayaç etkileşimi hakkında yapılan çalışmalarda kayaçlardaki kimyasal ayrışmanın su kimyasını doğrudan etkilediği görülmüştür (Davraz, 2003; Zhu, 2005; Scislewski ve Zuddas, 2010; Hamzaoui-Azaza vd., 2011).

Ilıman ve yağışlı bir iklime sahip Doğu Karadeniz Bölümü'nde engebeli topoğrafya sunan volkanik kayaçların çatlaklarından boşalan küçük debili kaynaklara sıklıkla rastlanmaktadır. Bir kısmı yöre halkı tarafından şifalı su olarak anılan bu kaynakların toplam çözünmüş madde miktarları genelde 500-1500 mg/l arasında değişiklik gösterir. Bu çalışmada normal yeraltı sularına göre daha fazla iyon içeriğine sahip bu sularda kayaç kimyasının su kimyası ve içilebilme özellikleri üzerine etkisi araştırılmak istenmiștir. $\mathrm{Bu}$ amaçla Aşağı Değirmendere (Trabzon-KD Türkiye) Havzası'nda yer alan ve çevre sakinleri tarafindan kullanılan Gözalan, Akoluk, Durali ve Yanlıca kaynakları incelenmiştir. Yörede daha önce yapılan çalışmalardan kaynakların
$\mathrm{pH}$ değerlerinin 5.5 ile 6.2, elektriksel iletkenlik değerlerinin ise 500 ile $1850 \mu \mathrm{S} / \mathrm{cm}$ (Gültekin vd., 2010), $\mathrm{CO}_{2}$ miktarlarının 16-6 ile $71.3 \mathrm{mg} / \mathrm{l}$ (Kara, 1997) arasında değiştiği belirtilmiştir. Gültekin vd. (2005) aynı alanda yaptıkları çalışmada bazı kaynaklarda $\mathrm{Cr}, \mathrm{Sb}$, $\mathrm{Se}$ ve $\mathrm{Pb}$ değerlerinin standartlarda verilen sinır değerleri aştığını belirtmişlerdir. Değirmendere Havzası'nda yüzey sularında yapılan çalışmada ise nitrit, nitrat, amonyum, fosfat ve sülfat değerlerinin sırasıyla $0.037 \mathrm{mg} / 1,3.85 \mathrm{mg} / \mathrm{l}$, $0.118 \mathrm{mg} / \mathrm{l}, 0.068 \mathrm{mg} / \mathrm{l}$ ve $18.5 \mathrm{mg} / \mathrm{l}$ (Alkan vd., 2013) olduğu belirlenmiştir.

İnceleme alanı Trabzon İli sınırları içerisinde olup, yaklaşık $1061 \mathrm{~km}^{2}$ 'lik yağış alanına sahip Değirmendere Havzası'nın aşağı kısımlarında yer alır (Şekil 1). Meteoroloji 11. Bölge Müdürlüğü'nün 1970-2012 yılları arasındaki kayıtlarına göre çalışma alanında ortalama toplam yıllık yağış $821.6 \mathrm{~mm}$ ve ortalama sıcaklık ise $14.7^{\circ} \mathrm{C}$ 'dir (MGM, 2015). Havzada en fazla yağış Ekim ayında, en düşük yağış ise Temmuz ayında kaydedilmiştir. Havzadaki yıllık gerçek buharlaşma-terleme miktarı ise $550 \mathrm{~mm}$ olarak hesaplanmıştır. Yoğun bitki örtüsü ile kaplı olan alan engebeli bir topoğrafyaya sahiptir. Dağınık ve kırsal yerleşimin olduğu çalışma alanında başlıca findık, kısmen sebze tarımı yapılmakta ve tarım faaliyetleri ile ilgili olarak tarımsal ilaç ve gübre kullanılmaktadır. 


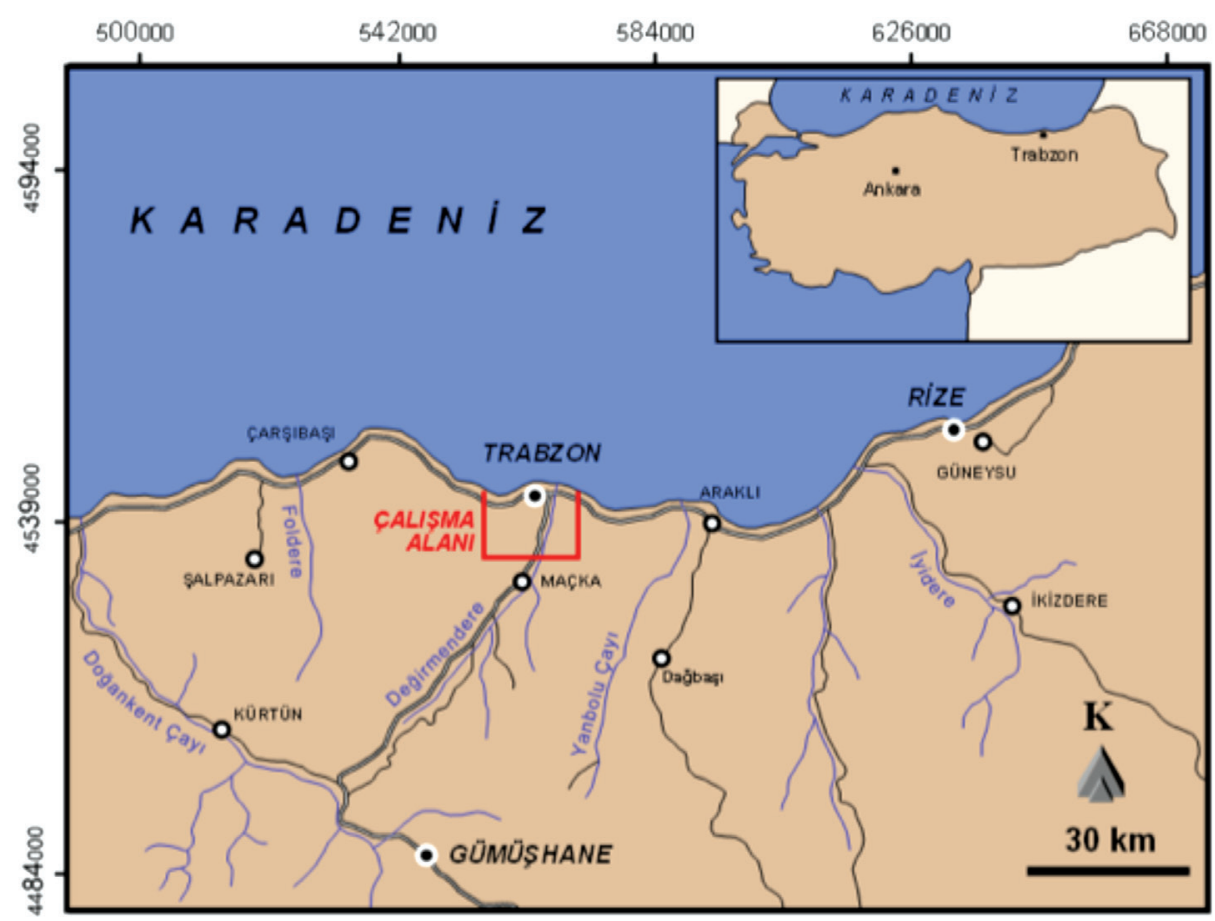

Şekil 1. İnceleme alanının yer bulduru haritası.

Figure 1. Location map of the study area.

\section{MATERYAL VE YÖNTEM}

Haziran 2012 tarihinde başlayıp, Mart 2013'te tamamlanan arazi çalışmaları sırasında jeolojik çalışmalar, kayaç ve su örneklemeleri ile yerinde su kimyası ölçümleri yapılmıştır. Jeolojik haritalama işlemleri, alanda daha önce yapılmış olan çalışmalardan revize edilmiştir. Kayaç jeokimyası için havzada yüzeylenen kayaçların ayrışmış ve ayrışmamış kısımlarından örnekler alınmıştır.

Kaynaklara ait sıcaklık, pH, debi, özgül elektriksel iletkenlik (ÖEI), toplam çözünmüş madde miktarı (TÇK) ve çözünmüş oksijen (ÇO) değerleri YSI 556 model çok parametreli ölçüm cihazı ile yerinde ölçülmüştür. Kaynaklardan Haziran 2012 tarihinde kimyasal ve izotopik analizler yapılmak üzere örnek alınmıştır. Örneklemede majör iyon analizleri için 1 litrelik, iz element analizleri için 100 ml'lik polietilen şişeler, Oksijen-18 ve Döteryum izotopu için $100 \mathrm{ml}$, trityum izotopu için 500 ml'lik polietilen şişeler kullanılmıştır. Örnek alınmadan önce şişeler 3 kez kaynak suyu ile çalkalanmıştır. Laboratuvar çalışmalarında alınan su örneklerinden majör iyon ve Trityum analizleri Hacettepe Üniversitesi, Hidrojeoloji Mühendisliği Anabilim Dalı $\mathrm{Su}$ Kimyası Laboratuvarı'nda, iz element analizleri ACME Analitik Laboratuvarı'nda (Kanada), Oksijen-18 ve Döteryum izotopları ISO ANALYTICAL (İngiltere) Laboratuvarı'nda yaptırılmıştır.

Kayaç örnekleri öncelikle Karadeniz Teknik Üniversitesi Jeoloji Mühendisliği Bölümü laboratuvarlarında ince kesit haline getirilerek polarizan mikroskopta incelenmiş ve kayaç türleri 
Tahmasebzadeh Bastam, Gültekin

tespit edilmiştir. Daha sonra her bir litolojiden seçilen ayrışmış ve ayrışmamış kayaç örnekleri aynı laboratuvarda çeneli kırıcıda kırılıp, bilyeli değirmende öğütülmüştür. Toz haline gelen örneklere ait tüm kayaç analizleri Ankara Üniversitesi Jeoloji Mühendisliği Bölümünde ICP-MS yöntemi ile analiz edilmiştir.

Suların farklı minerallere doygunluk durumlarının belirlenmesi için PhreeqC (Parkhurst ve Appelo, 1999) yazılımı kullanılmıştır.

\section{JEOLOJIKK-HİDROJEOLOJIK YAPI}

Çalışma alanında genellikle tortul ara seviyeler içeren volkanik kayaçlar yüzeylenir. Alandaki en yaşlı birim Geç Kretase yaşlı, altta koyu renkli bazalt, andezit ve piroklastitlerden, üst seviyelerde kırmızı mikritik kireçtaş1, killi kireçtaşı ve marnlardan oluşan Çağlayan formasyonudur (Güven, 1993). Bazalt ve andezitlerde kloritleşme ve epidotlaşma görülmektedir. Bazaltik yastık lavlarda gaz boşlukları genellikle kalsit, klorit ve zeolit gibi minerallerle dolmuştur. Çağlayan formasyonu, alt seviyelerde dasitik, riyolitik ve riyodasit ve bunların piroklastiklerinden, üst seviyelerde ise kumtaşı, killikireçtaşı, marn ve tüfile temsiledilen Çayırbağ formasyonu tarafından uyumlu olarak üstlenir (Güven, 1993). Geç Kretase-Paleosen yaşlı Tonya formasyonu (Korkmaz, 1993) genel olarak beyaz, açık gri, sarımsı renkli kireçtaş1, killi kumlu kireçtaşı ve marn ardalanmasından oluşur. Eosen-Neojen yaşlı Kabaköy formasyonu (Güven, 1993) inceleme alanında daha çok bazalt türü kayaçlarla temsil edilir. Birim yer yer kumtaşı, kumlu kireçtaşı ve marn ara tabakaları içeren masif veya kalın tabakalanmalı bol ojit ve hornblendli bazalt, andezit ve piroklastlarının oluşturduğu bir volkano tortul istiftir. Kabaköy formasyonu üzerine uyumsuz olarak gelen Pliyosen yaşlı Beşirli formasyonu (Güven, 1993) konglomera, kumtaşı ve tüflerden oluşmuştur (Şekil 2). Elemanlarının çoğunluğu çakıl, kum ve silt az miktarda da kilden oluşan alüvyonlar Değirmendere Havzası'nda güneyden kuzeye doğru genişleyen yüzeylemeler sunar.

Havzadaki birimleri genellikle volkanik kayaçlar oluşturmaktadır. $\mathrm{Bu}$ kayaçların geçirgenliklerini soğuma çatlaklarıile bozunmaya bağlı kırık-çatlak sistemleri denetlemektedir. Bazalt-andezittürü volkanik kayaçlarda prizmatik kolonsu yapılar belirgindir. Bu yapılar volkanik kayaçların birincil porozitelerini oluşturur. Tektonik faaliyetler sonucunda kazanmış oldukları çatlaklı oldukları çatlaklı yapı ikincil gözeneklilik olmayan bu geçirimli düzeyler yüzeyden beslenimin sığ derinliklere inmesini sağlar. Eğimli bir topoğrafyanın egemen olduğu alanda bu sı ğ derinliklere inen sular yamaçlardan genellikle küçük debili kaynaklar şeklinde boşalırlar. Dolayısıyla volkanik kayaçlar yeraltı suyu bakımından sadece çatlaklı oldukları yersel alanlarda önem taşımaktadır. Bu küçük kaynaklar mevsimlere bağlı olarak değişen debilerle boşalırlar. İnceleme alanında Geç Kretase yaşlı birimlerle Eosen yaşlı birimlerin faylı dokanağ ve kaynak sularının belirli bir hat boyunca dizim göstermeleri, incelenen kaynakların fay kaynağı olduğunu ifade etmektedir. 


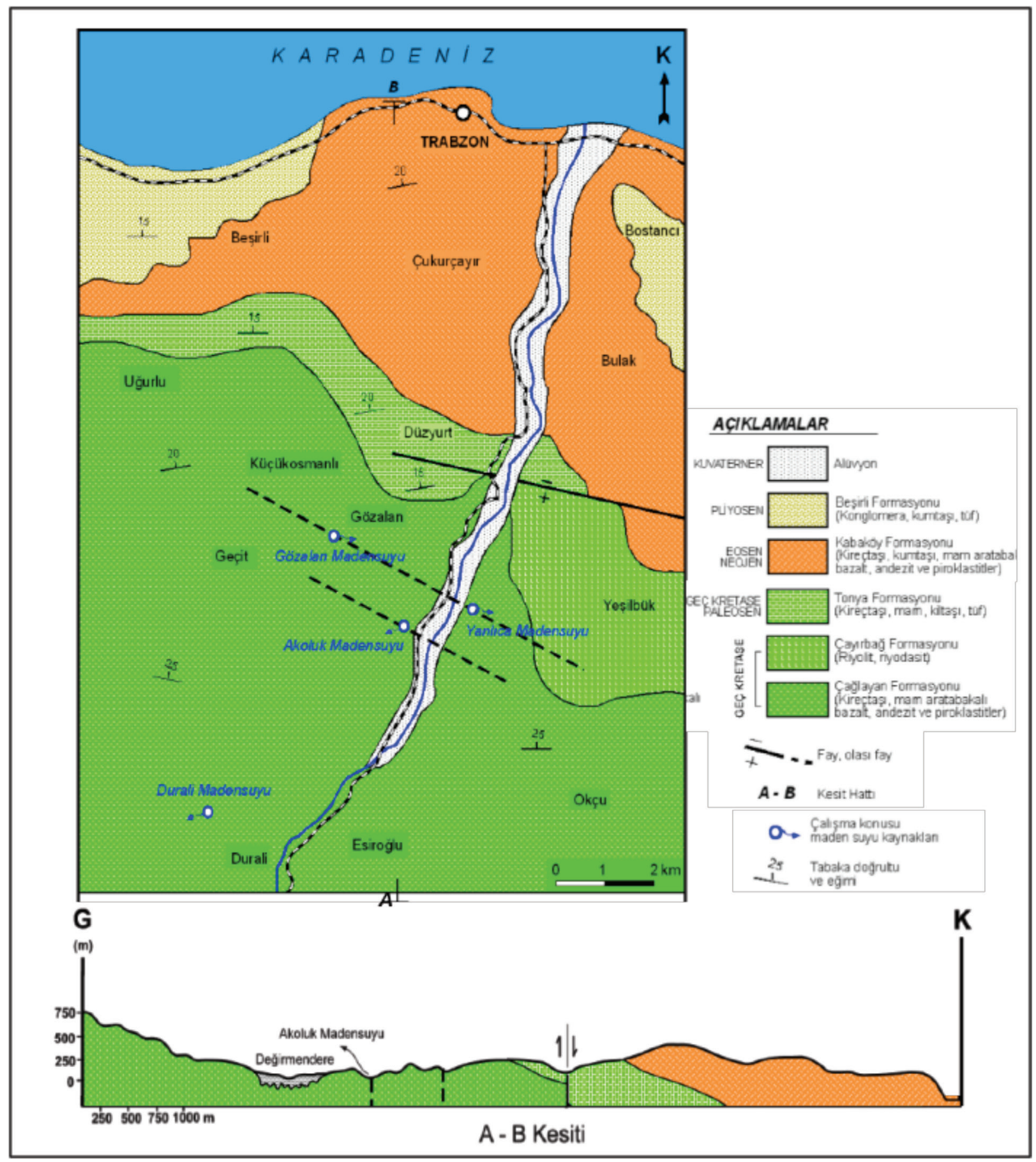

Şekil 2. Aşağ1 Değirmendere Havzası (Trabzon) jeoloji haritası (Güven, 1993 'ten değiştirilerek).

Figure 2. Geological map of the Lower Değirmendere Basin (Trabzon) (modified from Güven, 1993). 
Tahmasebzadeh Bastam, Gültekin

\section{KAYAÇ KIMYASI}

Geç Kretase yaşl1 farkl1 formasyonlardan alınan kayaçların makroskobik ve mikroskobik incelemelerinden genellikle bazalt, altere bazalt, andezit, altere andezit, tüf (andezitik ?), dasit, volkanik katkılı marn oldukları belirlenmiştir (Çizelge 1). Bazaltlar ve altere bazaltlar yaklaşık \% 70- $80 \mathrm{Ca}^{\prime} 1$ l plajioklas ve $\% 10$ ojit minerallerinden oluşmakta olup ikincil olarak kalsit ve kuvars mineralleri içerirler. Altere türlerinde ikincil mineral oranları daha düşüktür. Andezitler \% 75-80 Na'li plajioklas ve \% 1015 hornblend minerallerinden oluşmaktadır. Dasitler plajioklas, kuvars ve altere biyotitlerden meydana gelmiştir. Dasitik tüfler \% 30 kayaç parçası, $\% 70$ civarında kuvars, plajioklas ve diğer mineral tanelerinden oluşmuştur. Ayrışmış ve ayrışmamış kayaçların kimyasına göre; marnlar dışındaki tüm kayaçlarda (andezit, bazalt, dasit ve altere türleri) $\mathrm{SiO}_{2}$ en bol bulunan oksittir. İkinci sırada genellikle $\mathrm{Al}_{2} \mathrm{O}_{3}$ yer alır (Çizelge 1). Alterasyonun etkileri bazaltlarda $\mathrm{MgO}$ 'lerde $\% 30, \mathrm{Al}_{2} \mathrm{O}_{3}$ 'lerde \% 20 ve $\mathrm{Na}_{2} \mathrm{O}$ 'lerde \%10'luk artışlar, $\mathrm{CaO}$ 'lerde \% 25 ve $\mathrm{Fe}_{2} \mathrm{O}_{3}$ 'lerde \%20 'lik azalmalar şeklinde görülmektedir. Ayrışmış andezitik kayaçlarda \% 40- $50 \mathrm{Al}_{2} \mathrm{O}_{3}$ artışlarına karş1lı, \% 80- $90 \mathrm{Na}_{2} \mathrm{O}, \%$ 85- $90 \mathrm{CaO}, \%$ 30$80 \mathrm{MgO}$ değerlerinde azalmalar görülmektedir. Her iki kayaç grubunda $\mathrm{SiO}_{2}$ ve $\mathrm{K}_{2} \mathrm{O}$ değerleri ayrışmış türlerinde artmıştır. Kimyasal analizi yapılan kayaçların iz element değerleri ise Çizelge 2'de verilmiştir. Kayaçların iz element içerikleri incelendiğinde $\mathrm{Ba}, \mathrm{Sr}, \mathrm{Zr}, \mathrm{Rb}, \mathrm{Zn}$ ve $\mathrm{Ce}$ gibi iz elementlerin yüksek değerlerde, $\mathrm{Se}, \mathrm{Cd}, \mathrm{Sn}, \mathrm{Sb}$ ve $\mathrm{Hg}$ gibi elementlerin ise düşük değerlerde olduğu görülmüştür. Ayrışmış bazaltlarda Co, $\mathrm{Ni}, \mathrm{Cu}$ ve $\mathrm{Zn}$ dğerlerinde azalma, $\mathrm{Rb}, \mathrm{Sr}, \mathrm{Ba}$, $\mathrm{Cs}$ ve $\mathrm{Pb}$ değerlerinde artma gözlenmektedir. Andezitlerin ayrışmış türlerinde ise $\mathrm{Co}, \mathrm{Zn}$ ve Mo elementlerinde azalma, $\mathrm{Rb}, \mathrm{Zr}$ ve $\mathrm{Ba}$ elementlerinde artış görülmektedir. Çağlayan formasyonunu temsil eden altere andezitlerde iz element değerleri diğer kayaç türlerine göre daha yüksektir.

\section{SU KIMMYASI}

Değirmendere vadisindeki Gözalan, Akoluk, Durali ve Yanlıca kaynak sularının fizikokimyasal özellikleri Çizelge 3'te verilmiştir. İnceleme alanındaki kaynak sularının sicaklıkları $12.48-17.54{ }^{\circ} \mathrm{C}$, debileri $46-158 \mathrm{ml} /$ sn, pH değerleri 5.32-6.99, özgül elektriksel iletkenlik değerleri (ÖEİ) 603-1899 $\mu \mathrm{S} / \mathrm{cm}$, çözünmüş oksijen miktarı (ÇO) 3.20-9.35 mg/1 ve toplam çözünmüş madde miktarı (TÇK) 380-1230 mg/l arasında değişmektedir. $\mathrm{Bu}$ parametreler açısından kaynaklarda mevsimsel değişimler görülmemektedir. Akoluk kaynağında ilk ölçümlerde gözlenen farklılık, ölçümlerin kaynağın boru ile taşındığı yerde yapılmasından kaynaklanmaktadır. 


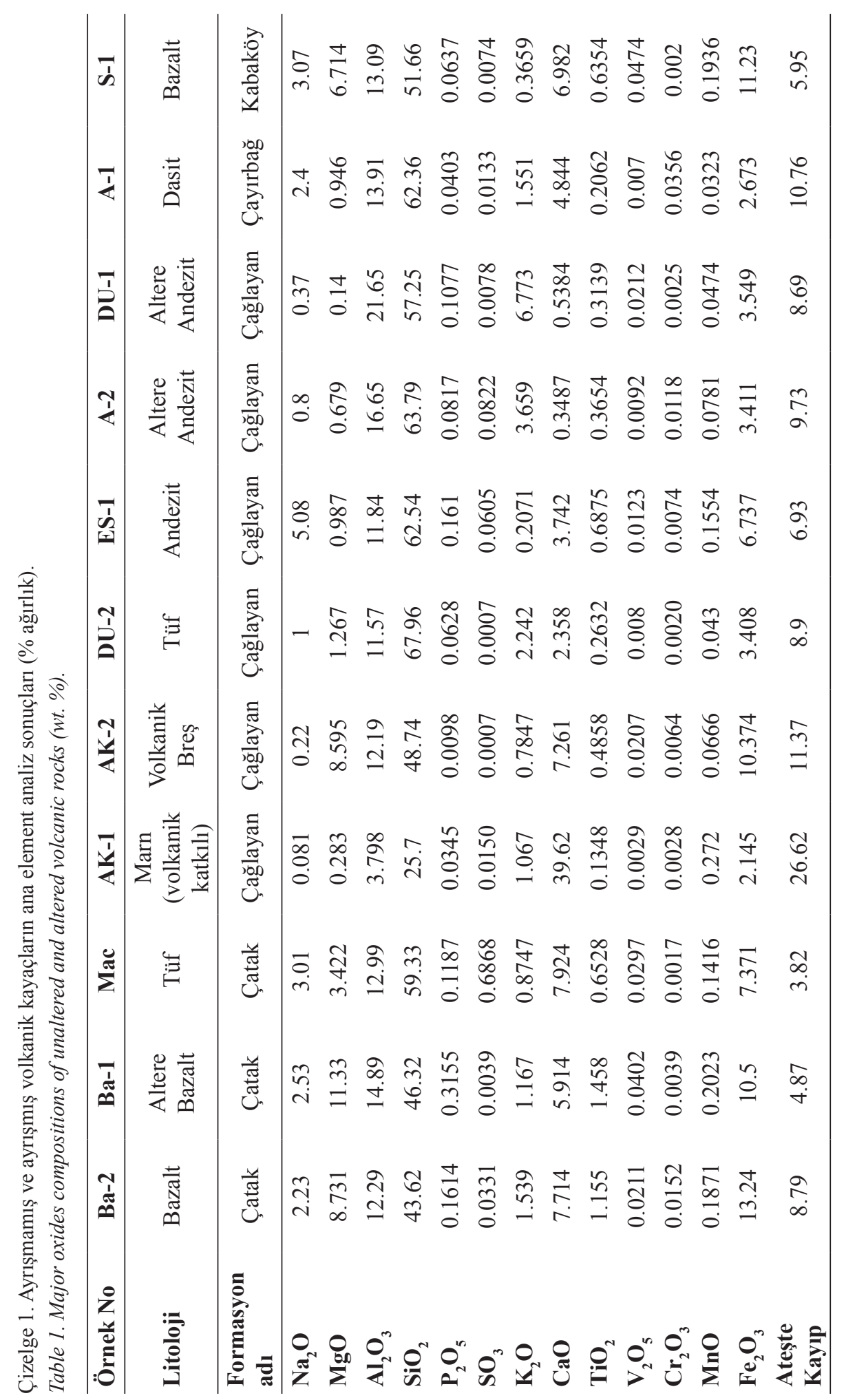


Tahmasebzadeh Bastam, Gültekin

Çizelge 2. Ayrışmamış ve ayrışmış volkanik kayaçların iz element analiz sonuçları (ppm). Table 2.Trace element results of unaltered and altered volcanic rocks (ppm).

\begin{tabular}{|c|c|c|c|c|c|c|c|c|c|c|c|}
\hline Element & Ba-2 & Ba-1 & Mac & AK-1 & AK-2 & DU-2 & ES-1 & A-2 & DU-1 & A-1 & S-1 \\
\hline Co & 56.7 & 51.7 & 29 & 16.5 & 53.7 & 35.7 & 37.2 & 17.8 & 22 & 16 & 43.9 \\
\hline Ni & 90.1 & 48.9 & 12.5 & 6.3 & 20.1 & 7.6 & 2.1 & 5 & 17.4 & 5.2 & 7.7 \\
\hline $\mathrm{Cu}$ & 4.6 & 5.3 & 17.6 & 17.4 & 40.3 & 10.5 & 7.2 & 15.9 & 6.1 & 6.3 & 38.6 \\
\hline $\mathbf{Z n}$ & 155.6 & 120.3 & 77.4 & 29.4 & 56.5 & 80.9 & 70 & 41 & 71.7 & 28.1 & 62.3 \\
\hline Ga & 15.3 & 19 & 14.9 & 6.9 & 15.4 & 17.4 & 11.7 & 15.6 & 23.9 & 11.9 & 11.8 \\
\hline Ge & 0.8 & 1.1 & 2.4 & 1.1 & 1.3 & 1.4 & 0.9 & 1.5 & 2.3 & 0.8 & 0.8 \\
\hline As & 3.7 & 3.9 & 17 & 5.5 & 3.3 & 2 & 5.8 & 5.2 & 5.1 & 1.4 & 1.2 \\
\hline Se & 0.5 & 0.5 & 0.5 & 0.5 & 0.4 & 0.4 & 0.4 & 0.4 & 0.7 & 0.3 & 0.4 \\
\hline $\mathrm{Br}$ & 0.4 & 0.4 & 0.4 & 0.9 & 0.3 & 0.4 & 0.9 & 1 & 1 & 0.3 & 0.4 \\
\hline $\mathbf{R b}$ & 22.3 & 25.1 & 25.9 & 62.3 & 14.1 & 57.8 & 1.3 & 48 & 77.6 & 23.8 & 3.7 \\
\hline $\mathrm{Sr}$ & 104 & 510.5 & 283.1 & 413.7 & 120.7 & 941 & 107.6 & 28.5 & 2974 & 71.1 & 239.5 \\
\hline $\mathbf{Y}$ & 29.9 & 28.2 & 21.7 & 13.8 & 3.9 & 64.5 & 28.4 & 43.6 & 25.7 & 22.9 & 8.6 \\
\hline $\mathrm{Zr}$ & 154.9 & 169.8 & 92.6 & 49.5 & 44.5 & 176.5 & 68.9 & 225.1 & 315 & 164.5 & 31.2 \\
\hline Nb & 8.1 & 6.5 & 6 & 3.6 & 3.1 & 11.2 & 3 & 3.3 & 96.1 & 2.7 & 3.5 \\
\hline Mo & 4.4 & 4.9 & 3.3 & 3.1 & 3.2 & 3.9 & 7.9 & 3.5 & 4.9 & 5.9 & 3.6 \\
\hline $\mathrm{Cd}$ & 1 & 1 & 0.8 & 0.9 & 0.8 & 1.4 & 0.8 & 1.3 & 1 & 0.7 & 1.2 \\
\hline Sn & 1.1 & 2.2 & 1.7 & 1.2 & 1.3 & 3.7 & 1.2 & 2.7 & 2 & 0.8 & 1 \\
\hline Sb & 1 & 1 & 2.8 & 1.1 & 0.9 & 1 & 0.9 & 0.9 & 1.1 & 0.9 & 1 \\
\hline Cs & 3.8 & 22.3 & 3.7 & 16.3 & 15.5 & 3.8 & 13.5 & 8.8 & 7.9 & 3.6 & 7 \\
\hline Ba & 360.4 & 469.7 & 154.1 & 174.8 & 53.8 & 280.6 & 57.5 & 163.2 & 2868 & 110.9 & 29.2 \\
\hline La & 29.5 & 72.7 & 31.5 & 75 & 48.9 & 7.6 & 40.1 & 35.9 & 146.7 & 35.4 & 19.9 \\
\hline $\mathrm{Ce}$ & 51.9 & 124.2 & 51 & 100.4 & 69.2 & 86.8 & 50.2 & 49.2 & 232.3 & 54.8 & 23.6 \\
\hline Hf & 5.1 & 4.8 & 6.3 & 4.8 & 5.8 & 3.7 & 3.7 & 5 & 4.2 & 3.7 & 6.1 \\
\hline Ta & 5.2 & 4.7 & 5 & 4.6 & 6.4 & 3.9 & 3.6 & 4 & 4.4 & 3.1 & 6.9 \\
\hline $\mathbf{W}$ & 6.4 & 5.5 & 4.2 & 4 & 3.9 & 3.9 & 4.4 & 2.9 & 4.5 & 3 & 4.3 \\
\hline Hg & 1.5 & 1.5 & 1.5 & 1.4 & 1.3 & 0.9 & 1.2 & 1.1 & 1.6 & 1 & 1.3 \\
\hline Tl & 1.7 & 1.7 & 1.7 & 1.2 & 1.3 & 1.2 & 1.2 & 1.1 & 1.6 & 1 & 1.4 \\
\hline $\mathbf{P b}$ & 9.3 & 18.5 & 62.8 & 25.5 & 1.4 & 7.3 & 4.2 & 2.3 & 51.8 & 7.5 & 1.4 \\
\hline Th & 1.7 & 1.5 & 6.5 & 5.8 & 1.2 & 3 & 1.1 & 4.5 & 75.5 & 4.6 & 0.4 \\
\hline $\mathbf{U}$ & 8.9 & 8.8 & 8.3 & 13.4 & 8.6 & 18.9 & 1.04 & 13 & 9.3 & 2.3 & 17.7 \\
\hline
\end{tabular}


Çizelge 3. Kaynak sularında yerinde ölçülen parametreler.

Table 3. In-situ measured parameters of springs waters.

\begin{tabular}{|c|c|c|c|c|c|c|}
\hline Parametreler & Kaynaklar & Haz.2012 & Ekim 2012 & Kas. 2012 & Ara. 2012 & Mart 2013 \\
\hline \multirow{4}{*}{$\begin{array}{c}\mathrm{T} \\
\left({ }^{\circ} \mathrm{C}\right)\end{array}$} & Gözalan & 13.9 & 13.9 & 13.8 & 13.7 & 13.6 \\
\hline & Akoluk & 15.1 & 17.5 & 13.5 & 12.5 & 12.9 \\
\hline & Durali & 13.3 & 14.4 & 14.8 & 13.6 & 12.8 \\
\hline & Yanlica & 13.9 & 14.4 & 14.2 & 14.2 & 13.9 \\
\hline \multirow{4}{*}{$\begin{array}{c}\mathbf{Q} \\
(\mathrm{ml} / \mathrm{sn})\end{array}$} & Gözalan & 71 & 69 & 65 & 61 & 84 \\
\hline & Akoluk & 46 & 46 & 50 & 48 & 52 \\
\hline & Durali & 78 & 101 & 142 & 173 & 158 \\
\hline & Yanlica & 82 & 81 & 87 & 95 & 92 \\
\hline \multirow{4}{*}{ pH } & Gözalan & - & 6.31 & 5.88 & 5.86 & 5.82 \\
\hline & Akoluk & - & 6.99 & 5.83 & 6.18 & 6.26 \\
\hline & Durali & - & 6.08 & 5.32 & 5.56 & 5.54 \\
\hline & Yanlica & - & 6.22 & 5.60 & 6.03 & 6.20 \\
\hline \multirow{4}{*}{$\begin{array}{c}\text { ÖEİ } \\
(\mu \mathrm{S} / \mathrm{cm})\end{array}$} & Gözalan & 1880 & 1899 & 1885 & 1872 & 1781 \\
\hline & Akoluk & 922 & 1710 & 1613 & 1587 & 1538 \\
\hline & Durali & 885 & 910 & 919 & 922 & 903 \\
\hline & Yanlica & 630 & 619 & 614 & 610 & 603 \\
\hline \multirow{4}{*}{$\begin{array}{c}\text { TÇK } \\
(\mathrm{mg} / \mathrm{l})\end{array}$} & Gözalan & 1220 & 1230 & 1220 & 1210 & 1150 \\
\hline & Akoluk & 590 & 1110 & 1040 & 1030 & 990 \\
\hline & Durali & 570 & 590 & 590 & 590 & 580 \\
\hline & Yanlica & 400 & 400 & 390 & 390 & 380 \\
\hline \multirow{4}{*}{$\begin{array}{c}\text { ÇO } \\
(\mathrm{mg} / \mathrm{l})\end{array}$} & Gözalan & 3.97 & 3.20 & 3.82 & 7.06 & 4.75 \\
\hline & Akoluk & 3.81 & 8.69 & 8.06 & 9.35 & 7.77 \\
\hline & Durali & 3.62 & 5.09 & 4.96 & 4.34 & 4.42 \\
\hline & Yanlica & 4.85 & 7.80 & 8.12 & 8.44 & 7.90 \\
\hline
\end{tabular}

Çalışma alanındaki kaynak sularının major iyon ve iz element içeriği Çizelge 4'te verilmiştir. Kaynaklarda en yüksek değere sahip iyonlar katyonlarda $\mathrm{Ca}^{+2}$, anyonlarda ise $\mathrm{HCO}_{3}{ }^{-’}$ tır. Piper diyagramına göre kaynak sularının $\mathrm{Ca}-\mathrm{HCO}_{3}{ }^{\prime} l u ̈$ su sinıfinda ve karbonat sertliklerinin \% 50'den fazla olduğu görülmektedir (Şekil 3a). Schoeller diyagramı ise suların kimyasal açıdan benzer bileşimde olduklarını göstermektedir (Şekil 3b).
Suların doygunluk durumlarının değişimi, hidrokimyasal evrimin safhalarını belirlemede yardımcı olur ve hangi kimyasal reaksiyonların su kimyası üzerinde etkili olduğunu göstermesi (Drever, 1997; Langmuir, 1997) açısından önemlidir. İnceleme alanında yüzeylenen volkanik kayaçlarda birincil olarak plajioklas ile ojit, hornblend ve kuvars gibi silikatl mineraller, ikincil olarak kalsit, kuvars ve klorit türü mineraller belirlenmiştir. Kayaçlarda 
bulunan bu minerallere göre kaynak sularının doygunluk durumları incelenmiş (Şekil 4), genel olarak montmorillonit, illit ve kaolinit gibi kil minerallerine aşırı doygun, götit, mika ve kuvars minerallerine doygun olduğu belirlenmiştir. Aşırı doygunluk uyumsuz çözünme, ortak iyon etkisi, hızlı sıcaklık artışı, buharlaşma ve $\mathrm{CO}_{2}$ kaybı gibi değişik faktörlerden meydana gelebilir (Appelo ve Postma, 1994; Langmuir, 1997). Sular kalsit, aragonit, albit, serizit, florit, $\mathrm{K}$ - feldispat, rodokrozit, siderit gibi minerallere doygun değildir. $\mathrm{Bu}$ durum kaynak sularının kimyasal gelişiminde silikatlı kayaç ayrışmasının karbonatlı kayaçlardan daha etkili olduğunu göstermektedir.

\section{DOĞAL İZOTOPLAR}

Son yıllarda izotop çalışmaları ile suyun kökeni, beslenme alanı ve su-kayaç etkileşimleri gibi konulara açıklık getirilebilmektedir. İncelenen kaynak sularında $\delta^{18} \mathrm{O}, \quad \delta^{2} \mathrm{H}$ ve ${ }^{3} \mathrm{H}$ çevresel izotop içerikleri belirlenmiştir. Kaynakların $\delta^{18} \mathrm{O}$ değerleri -9.64 ile $-8.89(\%$
SMOW), $\delta^{2} \mathrm{H}$ değerleri -60.42 ile -56.23 (\%o SMOW) ve trityum değerleri $6.60-8.40 \mathrm{TU}( \pm$ 0.40) arasında olup bu değerlere göre kaynak suları meteorik kökenlidir. Küresel Meteorik Su Doğrusu (Craig, 1961), Doğu Karadeniz Meteorik Su Doğrusu (DKMD: $\delta^{2} \mathrm{H}=8 \delta^{18} \mathrm{O}+16$ ) (Ekmekçi ve Gültekin, 2015) ve kaynakların $\delta^{18} \mathrm{O}-\delta^{2} \mathrm{H}$ ilişkileri Şekil 5a'da verilmiştir. İncelenen kaynak suları DKMD üzerinde yer almaktadır. $\delta^{2} \mathrm{H}$ değeri daha küçük olan Gözalan kaynağının diğer kaynaklara göre daha yüksek kotlardan beslendiği, Durali kaynağında ise göreceli olarak bir $\delta^{18} \mathrm{O}$ zenginleşmesi olduğu söylenebilir. Kaynak sularının birbirlerine göre bağıl yeraltında kalış süreleri trityum-klorür ilişkisi (Şekil 5b) ile belirlenmeye çalışılmıştır. Trityum değerleri arasında çok büyük farklar bulunmamakla beraber yüksek trityum değerleri Gözalan ve Akoluk kaynaklarında, nispeten yüksek klorür değeri ise Yanlıca kaynağında görülmektedir. $\mathrm{Bu}$ durum Yanlıca kaynak suyunun yeraltında kalış süresinin kısmen diğer kaynaklara göre daha uzun olabileceğini göstermektedir.

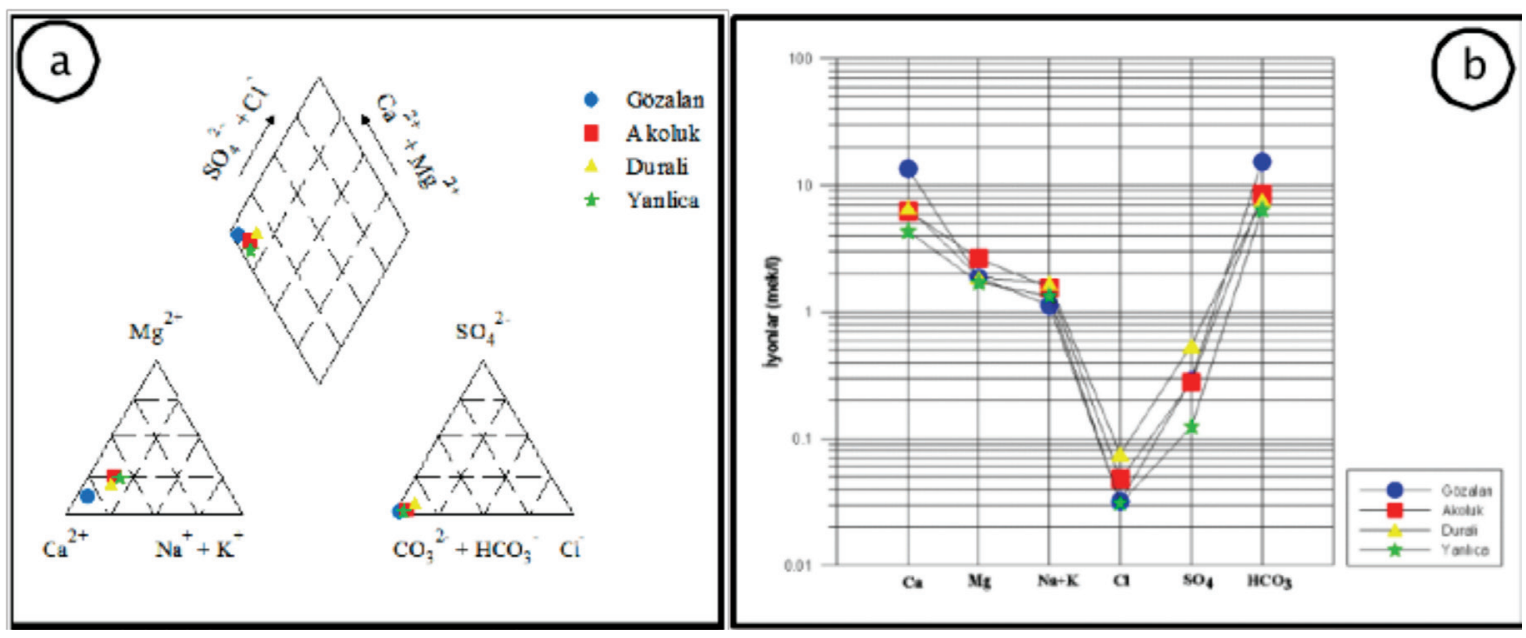

Şekil 3. Kaynak suyu örneklerinin Piper (a) ve Schoeller (b) diyagramları.

Figure 3. Piper diagram (a) and Schoeller diagram (b) of the spring water samples. 
Çizelge 4. Kaynak sularının kimyasal analiz sonuçları (mg/l).

Table 4. Results of chemical analysis of springs waters (in $\mathrm{mg} / \mathrm{l}$ ).

\begin{tabular}{|c|c|c|c|c|}
\hline Parametre & Gözalan & Akoluk & Durali & Yanlıca \\
\hline $\mathrm{Ca}^{+2}$ & 270.1 & 125.6 & 86.5 & 134.3 \\
\hline $\mathbf{M g}^{+2}$ & 22.3 & 31.5 & 20.6 & 22.6 \\
\hline $\mathbf{N a}^{+}$ & 22.3 & 35.2 & 30.0 & 37.6 \\
\hline $\mathbf{K}^{+}$ & 6.2 & 1.0 & 1.0 & 2.0 \\
\hline $\mathrm{HCO}_{3}^{-}$ & 941.0 & 519.2 & 389.4 & 467.2 \\
\hline $\mathrm{SO}_{4}^{-2}$ & 14.0 & 13.5 & 6.0 & 26.2 \\
\hline $\mathrm{Cl}^{-}$ & 11.4 & 17.4 & 11.1 & 27.2 \\
\hline $\mathbf{F}^{-}$ & 0.27 & 0.21 & 0.04 & 0.12 \\
\hline $\mathrm{SiO}_{2}$ & 44.5 & 33.5 & 84.4 & 88.5 \\
\hline $\mathrm{NO}_{2}$ & $<0.01$ & $<0.01$ & $<0.01$ & 0.07 \\
\hline $\mathrm{NO}_{3}$ & 10.45 & 33.9 & 50.37 & 14.5 \\
\hline $\mathrm{PO}_{4}$ & $<0.01$ & $<0.01$ & $<0.01$ & $<0.01$ \\
\hline $\mathbf{N H}_{4}$ & 0.82 & 0.52 & 0.45 & 0.25 \\
\hline Al & $<0.001$ & $<0.001$ & $<0.001$ & $<0.001$ \\
\hline As & 0.0009 & 0.0009 & 0.0009 & 0.0008 \\
\hline B & 0.032 & 0.037 & 0.014 & 0.023 \\
\hline $\mathbf{B a}$ & 0.48995 & 0.05022 & 0.02299 & 0.00309 \\
\hline $\mathrm{Br}$ & 0.024 & 0.036 & 0.046 & 0.04 \\
\hline Cd & $<0.00005$ & $<0.00005$ & $<0.00005$ & $<0.00005$ \\
\hline $\mathrm{Cr}$ & 0.0625 & 0.0304 & 0.0351 & 0.0267 \\
\hline Cs & 0.00021 & $<0.00001$ & 0.00042 & $<0.00001$ \\
\hline $\mathrm{Cu}$ & 0.0007 & 0.0004 & 0.0005 & 0.0003 \\
\hline $\mathbf{F e}$ & $<0.01$ & $<0.01$ & $<0.01$ & $<0.01$ \\
\hline $\mathbf{L i}$ & 0.0057 & 0.0015 & 0.0053 & 0.0024 \\
\hline Mn & $<0.00005$ & $<0.00005$ & 0.01075 & 0.00038 \\
\hline Мо & $<0.0001$ & 0.0001 & $<0.0001$ & $<0.0001$ \\
\hline $\mathbf{P b}$ & $<0.0001$ & $<0.0001$ & $<0.0001$ & $<0.0001$ \\
\hline $\mathbf{R b}$ & 0.01776 & 0.00056 & 0.00355 & 0.00018 \\
\hline Sc & 0.01 & 0.006 & 0.013 & 0.012 \\
\hline Se & 0.001 & 0.0006 & 0.0025 & 0.0008 \\
\hline $\mathrm{Sr}$ & 1.65287 & 0.43925 & 0.30241 & 0.17113 \\
\hline $\mathbf{U}$ & 0.00246 & 0.00148 & 0.00025 & 0.00009 \\
\hline $\mathbf{Z n}$ & $<0.0005$ & $<0.0005$ & 0.0084 & $<0.0005$ \\
\hline
\end{tabular}


Tahmasebzadeh Bastam, Gültekin

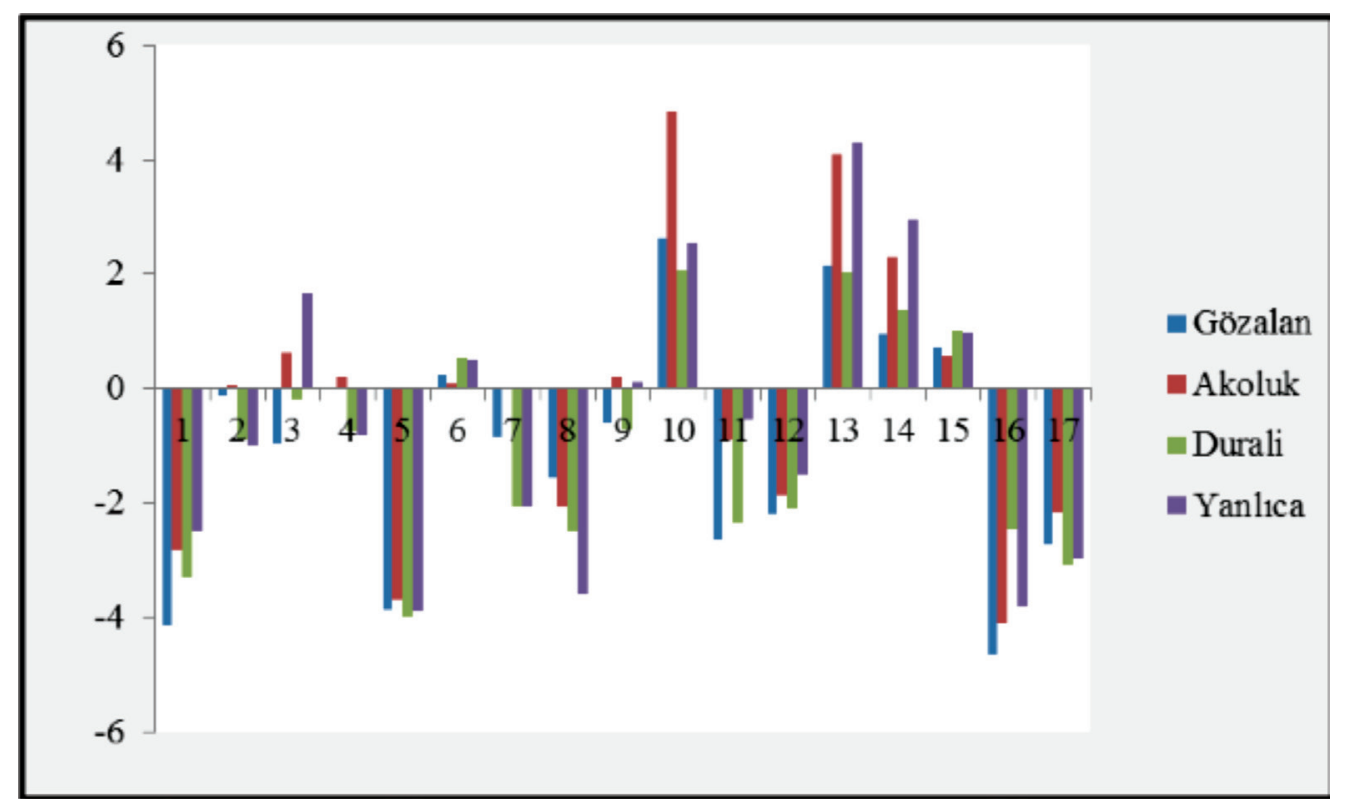

Şekil 4. Seçilen bazı minerallere göre doygunluk indisleri (SI). 1:albit, 2:aragonit, 3:Ca- montmorillonit, 4:kalsit, 5:seruzit, 6: kalsedon, 7:dolomit, 8:florit, 9:gibsit, 10:götit, 11:illit, 12:K- feldispat, 13:K-mika, 14:kaolinit, 15:kuvars, 16:rodokrozit, 17:siderit).

Figure 4. Saturation indices (SI) of some selected minerals. (1:albite, 2:aragonite, 3:Ca-montmorillonite, 4:calcite, 5:cerusite, 6: chalcedony, 7:dolomite, 8:fluorite, 9:gibbsite, 10:goethite, 11:illite, 12:K-feldspar, 13:K-mica, 14:kaolinite, 15:quartz, 16:rhodochrosite, 17:siderite).
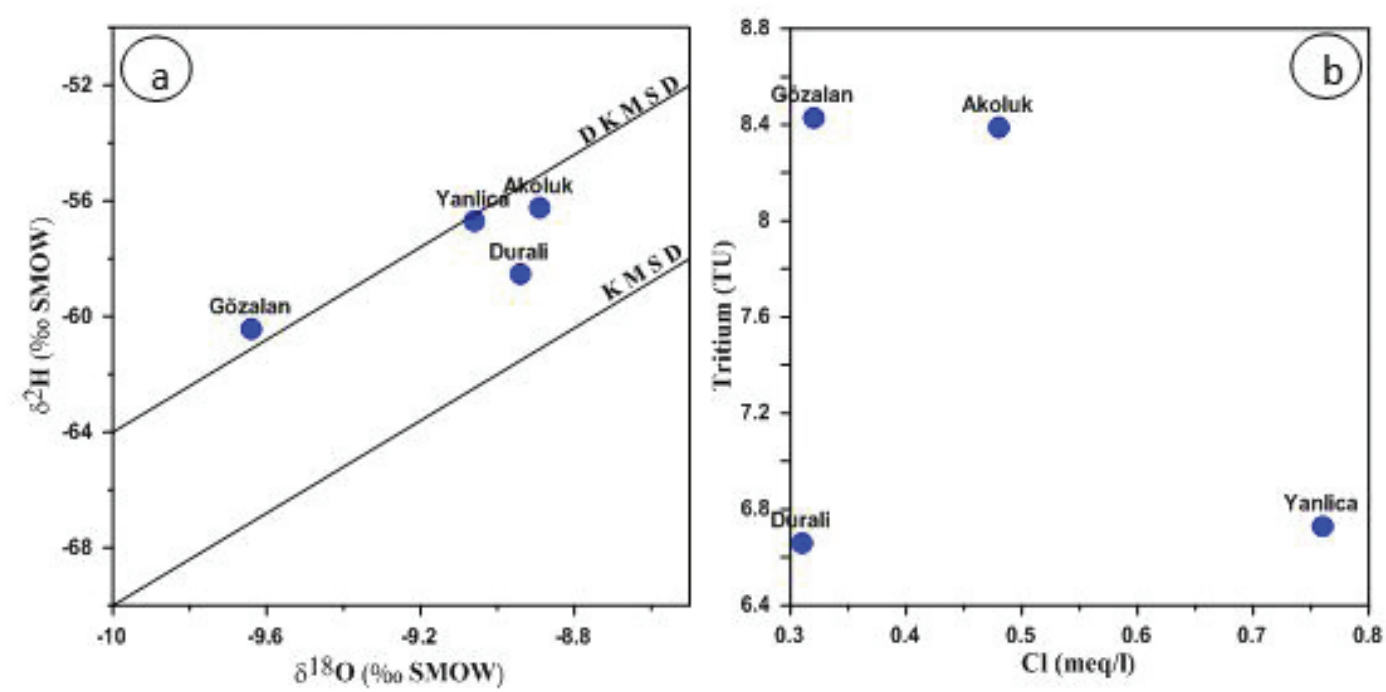

Şekil 5. İncelenen kaynak sularında $\delta^{18} \mathrm{O}-\delta^{2} \mathrm{H}$ (a) ve Cl-Trityum (b) ilişsisi. (KMSD: Küresel Meteorik Su Doğrusu, DKMSD: Doğu Karadeniz Meteorik Su Doğrusu).

Figure 5. $\delta^{18} \mathrm{O}-\delta^{2} \mathrm{H}(\mathrm{a})$ and $\mathrm{Cl}-$ Tritium (b) relation for the studied spring waters (KMSD: Global Meteoric Water Line, DKMSD: Eastern Black Sea Meteoric Water Line). 


\section{SU- KAYAÇ ETKILEŞİMI}

Yeraltı sularındaki majör iyon derişimlerini karbonat ayrışması ve çökelmesi, silikat ayrışmas1, iyon değişimi ve buharlaşma gibi hidrojeokimyasal süreçler kontrol etmektedir. Silikat ayrışmasının, yeraltı suyundaki $\mathrm{SiO}_{2}$, $\mathrm{Ca}^{2+}, \mathrm{Mg}^{2+}, \mathrm{Na}^{+}$ve $\mathrm{K}^{+}$derişimleri, kalsit ve dolomit gibi karbonat ayrışmasının $\mathrm{Ca}^{2+} \mathrm{Mg}^{2+}$ ${ }^{\text {ve }} \mathrm{HCO}_{3}^{-}$derişimleri açısından etkili olduğu bilinmektedir. Buharlaşma sürecinin etkileri ise $\mathrm{Na}^{+}$ve $\mathrm{Cl}^{-}$iyonları ile TÇK değerlerinde gözlenmektedir (Gibbs, 1970). İncelenen kaynak sularında TÇK değerlerinin 400-1250 mg/l ve $\left(\mathrm{Na}^{++} \mathrm{K}^{+}\right) /\left(\mathrm{Na}^{++} \mathrm{K}^{+}+\mathrm{Ca}^{2+}\right)$ oranlarının 0.09-0.26 arasında olması, kaynak sularının kimyasını başlıca su-kayaç etkileşiminin kontrol ettiğini göstermektedir. Beslenme havzalarında kireçtaşı, kumlu kireçtaşı, killi kireçtaşı ve marn arakatkılı bazalt, andezit ve dasit türü volkanik kayaçlar yüzeylenen kaynak sularında en fazla bulunan katyon 86.5-270.1 mg/l değerleri ile $\mathrm{Ca}^{+2}$, en fazla bulunan anyon ise $389.4-941 \mathrm{mg} / 1$ değerleri ile $\mathrm{HCO}_{3}{ }_{3}^{-}$tür. Kaynaklarda $\mathrm{Mg}^{+2}$ 20.6-31.5 mg/1, $\mathrm{Na}^{+}$ ise $22.3-37.6 \mathrm{mg} / 1$ arasında değişen değerlerde bulunur. Silikatlı arazilerde yapilan su kimyası çalışmalarında $\mathrm{Ca}^{+2}$ ve $\mathrm{HCO}_{3}^{-}$iyonlarının mek/1 cinsinden oranının 1:2 olduğunda kalsit, 1:4 olduğunda dolomit çözünmesinin etkili olduğu belirtilmiştir (Garrels ve Mackenzie, 1971). Kaynaklarda bu oranın 0.67-0.88 arasında olması kalsit ve dolomit dışındaki kayaç ayrışmasının daha etkili olduğunu göstermektedir. Majör iyonların hangi kimyasal olaylar sonucu sukayaç etkileşimi ile suya geçmiş olabilecekleri Hounslow (1995)'e göre değerlendirilmiş ve incelenen kaynakları etkileyen kimyasal süreçler belirlenmiştir (Çizelge 5). Çizelge 5'e göre kaynak sularının kimyasal gelişiminde plajioklas ayrışması, ferromagnezyen mineraller içeren silikat ayrışması, iyon değişimi ve karbonat ayrışması süreçleri etkili olmuştur.

$\left(\mathrm{Na}^{+}+\mathrm{K}^{+}-\mathrm{Cl}^{-}\right) /\left(\mathrm{Na}^{+}+\mathrm{K}^{+}-\mathrm{Cl}^{-}+\mathrm{Ca}^{+2}\right)$ oranının $<0.2$ ve $\mathrm{Na}^{+} /\left(\mathrm{Na}^{+}+\mathrm{Cl}^{-}\right)$oranının $>0.5$ olmasi $\mathrm{Na}^{+}$ iyonlarının kaynağının plajioklas ayrışması ve iyon değişimi olduğunu göstermektedir. $\mathrm{HCO}_{3}^{-} /$ $\mathrm{SiO}_{2}>10$ veya $<5$ olma durumu karbonat veya silikat ayrışmasını gösterir (Hounslow, 1995). Ancak çevre kayaçların bileşimleri ve $\mathrm{Ca}$ ve $\mathrm{HCO}_{3}$ oranları dikkate alındığında çalışma alanındaki suların kimyası üzerinde silikat ayrışmasının karbonat ayrışmasından daha etkili olduğu söylenebilir. Doğal sularda genellikle 1-30 mg/l (Hem, 1970) arasinda bulunan $\mathrm{SiO}_{2}$, incelenen kaynak sularında 33.5 ile $88.5 \mathrm{mg} / 1$ arasında değişir. Silikatların bozunması albit, anortit, K-feldispat, piroksen ve biyotitin kaolinite dönüşme reaksiyonları (1-5) eşitlikleri (Appelo ve Postma, 1994), amfibolün ayrışma reaksiyonu ise (6) eşitliği (Sami, 1992) ile verilmiştir. 
Tahmasebzadeh Bastam, Gültekin

Çizelge 5. İncelenen kaynak sularında gelişen su-kayaç etkileşim süreçleri (Hounslow, 1995).

Table 5. Water-rock interaction processes in the investigated spring waters (Hounslow, 1995).

\begin{tabular}{|c|c|c|c|c|}
\hline Parametre ve süreç & Gözalan & Akoluk & Durali & Yanlica \\
\hline $\begin{array}{c}\left(\mathrm{Na}^{+}+\mathrm{K}^{+}-\mathrm{Cl}^{-}\right) / \\
\left(\mathrm{Na}^{+}+\mathbf{K}^{+}-\mathrm{Cl}^{-}+\mathbf{C a}^{+2}\right)\end{array}$ & $\begin{array}{c}0.07 \\
\text { Plajioklas Ayrışmas1 }\end{array}$ & $\begin{array}{c}0.19 \\
\text { Plajioklas Ayrışmas1 }\end{array}$ & $\begin{array}{c}0.19 \\
\text { Plajioklas Ayrışması }\end{array}$ & $\begin{array}{c}0.23 \\
\text { Olası Plajioklas } \\
\text { Ayrışması }\end{array}$ \\
\hline $\mathrm{Na}^{+} /\left(\mathrm{Na}^{+}+\mathrm{Cl}^{-}\right)$ & $\begin{array}{c}0.96 \\
\text { Iyon değişimi }\end{array}$ & $\begin{array}{c}0.96 \\
\text { Iyon değişimi }\end{array}$ & $\begin{array}{c}0.98 \\
\text { Iyon değişimi }\end{array}$ & $\begin{array}{c}0.97 \\
\text { Iyon değişimi }\end{array}$ \\
\hline $\begin{array}{c}\mathrm{HCO}_{3}^{-} / \mathrm{SiO}_{2} \\
\mathrm{Mg}^{+2} /\left(\mathbf{C a}^{+2}+\mathbf{M g}^{+2}\right)\end{array}$ & $\begin{array}{c}21.13 \\
0.12 \\
\text { Karbonat } \\
\text { ayrışmas1 }\end{array}$ & $\begin{array}{c}15.5 \\
0.29 \\
\text { Karbonat } \\
\text { ayrışması }\end{array}$ & $\begin{array}{c}4.61 \\
0.21 \\
\text { silikat ayrışması } \\
\text { (Ferromagnezyen } \\
\text { mineraller) }\end{array}$ & $\begin{array}{c}5.2 \\
0.28 \\
\text { silikat ayrışması } \\
\text { (Ferromagnezyen } \\
\text { mineraller) }\end{array}$ \\
\hline $\mathrm{Ca}^{+2} /\left(\mathrm{Ca}^{+2}+\mathrm{SO}_{4}^{-2}\right)$ & $\begin{array}{c}0.97 \\
\text { Karbonat veya } \\
\text { silikat ayrışması }\end{array}$ & $\begin{array}{c}0.95 \\
\text { Karbonat veya } \\
\text { silikat ayrışması }\end{array}$ & $\begin{array}{c}0.92 \\
\text { Karbonat veya } \\
\text { silikat ayrışması }\end{array}$ & $\begin{array}{c}0.97 \\
\text { Karbonat veya } \\
\text { silikat ayrışması }\end{array}$ \\
\hline$\left(\mathrm{Ca}^{+2}+\mathrm{Mg}^{+2}\right) / \mathrm{SO}_{4}^{-2}$ & $\begin{array}{c}52.78 \\
\text { Dedolomitleşme yok }\end{array}$ & $\begin{array}{c}31.63 \\
\text { Dedolomitleşme yok }\end{array}$ & $\begin{array}{c}15.77 \\
\text { Dedolomitleşme yok }\end{array}$ & $\begin{array}{c}48.66 \\
\text { Dedolomitleşme yok }\end{array}$ \\
\hline $\mathrm{Cl}^{-} /$इanyon & $\begin{array}{c}0.002 \\
\text { Kayaç ayrışması }\end{array}$ & $\begin{array}{c}0.005 \\
\text { Kayaç ayrışması }\end{array}$ & $\begin{array}{c}0.009 \\
\text { Kayaç ayrışması }\end{array}$ & $\begin{array}{c}0.004 \\
\text { Kayaç ayrışması }\end{array}$ \\
\hline $\mathrm{HCO}_{3}^{-/ 2 \text { anyon }}$ & $\begin{array}{c}0.97 \\
\text { silikat veya karbonat } \\
\text { ayr. }\end{array}$ & $\begin{array}{c}0.96 \\
\text { silikat veya karbonat } \\
\text { ayr. }\end{array}$ & $\begin{array}{c}0.92 \\
\text { silikat veya karbonat } \\
\text { ayr. }\end{array}$ & $\begin{array}{c}0.97 \\
\text { silikat veya karbonat } \\
\text { ayr. }\end{array}$ \\
\hline
\end{tabular}

*Çizelgede iyon derişimleri mg/l'dir.

$2 \mathrm{NaAlSi}_{3} \mathrm{O}_{8}+2 \mathrm{H}^{+}+9 \mathrm{H}_{2} \mathrm{O} \rightarrow \mathrm{Al}_{2} \mathrm{Si}_{2} \mathrm{O}_{5}(\mathrm{OH})_{4+} 2 \mathrm{Na}^{+}+4 \mathrm{H}_{4} \mathrm{SiO}_{4}$

Albit Kaolinit

$2 \mathrm{CaAl}_{2} \mathrm{Si}_{2} \mathrm{O}_{8}+2 \mathrm{H}^{+}+\mathrm{H}_{2} \mathrm{O} \rightarrow \mathrm{Al}_{2} \mathrm{Si}_{2} \mathrm{O}_{5}(\mathrm{OH})_{4+} 2 \mathrm{Ca}^{2+}$

Anortit

$2 \mathrm{KAlSi}_{3} \mathrm{O}_{8}+2 \mathrm{H}^{+}+9 \mathrm{H}_{2} \mathrm{O} \rightarrow \mathrm{Al}_{2} \mathrm{Si}_{2} \mathrm{O}_{5}(\mathrm{OH})_{4+} 2 \mathrm{~K}^{+}+4 \mathrm{H}_{4} \mathrm{SiO}_{4}$

K-feldispat

$\left[\mathrm{CaMg}_{0} \cdot{ }_{7} \mathrm{Al}_{3} \mathrm{Si}_{1.7}\right] \mathrm{O}_{6}+3.4 \mathrm{H}^{+}+1.1 \mathrm{H}_{2} \mathrm{O}$

Piroksen $\rightarrow 0.3 \mathrm{Al}_{2} \mathrm{Si}_{2} \mathrm{O}_{5}(\mathrm{OH})_{4+} \mathrm{Ca}^{2+}+0.7 \mathrm{Mg}^{2+}+1.1 \mathrm{H}_{4} \mathrm{SiO}_{4}$

$2 \mathrm{~K}\left[\mathrm{Mg}_{2} \mathrm{Fe}\right]\left[\mathrm{AlSi}_{3}\right] \mathrm{O}_{10}(\mathrm{OH})_{2}+10 \mathrm{H}^{+}+0.5 \mathrm{O}_{2}+7 \mathrm{H}_{2} \mathrm{O}$

Biyotit $\rightarrow \mathrm{Al}_{2} \mathrm{Si}_{2} \mathrm{O}_{5}(\mathrm{OH})_{4}+2 \mathrm{~K}^{+}+4 \mathrm{Mg}^{2+}+2 \mathrm{Fe}(\mathrm{OH})_{3}+4 \mathrm{H}_{4} \mathrm{SiO}_{4}$

$\mathrm{Ca}_{2} \mathrm{Mg}_{5} \mathrm{Si}_{8} \mathrm{O}_{22}(\mathrm{OH})_{2}+14 \mathrm{CO}_{2}+22 \mathrm{H}_{2} \mathrm{O}$

Amfibol $\rightarrow 2 \mathrm{Ca}^{2+}+5 \mathrm{Mg}^{2+}+14 \mathrm{HCO}_{3}^{-}+8 \mathrm{Si}(\mathrm{OH})_{4}$ 
Kaynak sularındaki $\mathrm{Ca}^{+2}$ 'un kaynağını çoğunlukla çevre kayaçlarda yaklaşık \% 7080 oranında bulunan Ca'lu plajioklaslar, \% 5-10 oranındaki ojit ve hornblend gibi silikatlı mineraller, az miktarda da volkanik kayaçlarda ikincil mineral olarak bulunan kalsit ve ara seviyeler şeklinde bulunan kireçtaşları oluşturur. $\mathrm{Mg}^{+2}$ ise sulara volkanik kayaçlardaki piroksen, amfibol ve biyotit gibi koyu renkli minerallerden geçmiştir. $\mathrm{Na}^{+}$ise andezit, altere andezit ve dasit türü volkanik kayaçlarda $\% 70$ oranında bulunan Na'ca zengin plajioklasların ayrışması ve katyon değişimi olayları sonucu yeraltı suyuna karışmıştır. Havzada volkanik kayaçlarda yapılan ayrıntılı petrografik çalışmalarda (Aydın, 2003) feldispatoitlerde sodalitlerin ve opak mineral olarak piritlerin bulunduğu belirtilmiştir. $\mathrm{Bu}$ mineraller sularda düşük derişimlerde bulunan $\mathrm{Cl}^{-}(11.1-27.2 \mathrm{mg} / \mathrm{l})$ ve $\mathrm{SO}_{4}^{-2}(6-26.2 \mathrm{mg} / \mathrm{l})$ iyonlarının kaynağ1 olarak düşünülmektedir.

Kaynak sularında gelişen su-kayaç etkileşim süreçlerinde iyon değişiminin de etkili olduğu görülmüştür. $\mathrm{Bu}$ nedenle yeraltı suyu ile çevre kayaçlar arasındaki iyon değişimini açıklamak için Schoeller (1965 ve 1967) tarafından önerilen CAI (Chloro Alkaline
Indices) indisleri hesaplanmıştır (Çizelge 6). Sulardaki $\mathrm{Na}^{+}$ve $\mathrm{K}^{+}$ile kayaçlardaki $\mathrm{Ca}^{+2}$ ve $\mathrm{Mg}^{+2}$ ' un yer değiştirmesi doğrudan değiş tokuş, değişimin tersi olduğu durum ise ters değiş tokuş olarak adlandırılmaktadır. Doğrudan değiş tokuş işleminde indislerin her ikisi de pozitif, tersi durumda negatif değerler almaktadır. Kaynak suları için hesaplanan CAI indislerinin negatif değerler alması (Çizelge 6), ters değişimin olduğunu göstermektedir.

Kil mineralleri gibi kolloid boyutunda partikül içeren jeolojik birimlerde, partikül yüzeylerinde adsorplanmış iyonik bileşenler sudaki diğer iyonlarla yer değiştirme yeteneğine sahiptir. Bu tür iyonik yer değiştirmenin neden olduğu yüzey yükünün karakteri pH'a bağl1dır (Freeze ve Cherry, 1979; Appelo ve Postma, 1994). Yeraltı sularının $\mathrm{pH}$ değeri (6.5-8.5) kaolinit ve montmorillonit türü kil minerallerinin $\mathrm{pH}_{\mathrm{pzc}}$ değerlerinden (4.6 ve 2.5) büyük olduğu için bu mineraller katyon absorplama eğilimindedir (Appelo ve Postma, 1994). pH değerleri 5.3 ile 6.9 arasında olan kaynaklarda, sulardaki $\mathrm{Ca}^{+2}$ ile kil minerallerine tutunmuş olan $\mathrm{Na}^{+}$'un yer değiştirmesinden söz edilebilir.

Çizelge 6. İncelenen kaynak sularında CAI (Chloro Alkaline Indices) indisleri.

Table 6. CAI (Chloro Alkaline Indices) of the studied spring waters.

\begin{tabular}{ccccc}
\hline CAI & Gözalan & Akoluk & Durali & Yanlıca \\
\hline $\mathrm{r} \frac{\mathrm{Cl}-\left(\mathrm{Na}^{+}+\mathrm{K}^{+}\right)}{\mathrm{Cl}^{-}}$ & -1.128 & -1.55 & -1.68 & -1.32 \\
$\mathrm{r} \frac{\mathrm{Cl}^{-}-\left(\mathrm{Na}^{+}+\mathrm{K}^{+}\right)}{\mathrm{SO}_{4^{-2}+\mathrm{HCO}_{3}+\mathrm{NO}_{3}^{-}}}$ & -0.055 & -0.13 & -0.14 & -0.15 \\
\hline
\end{tabular}


Florür değerleri ise $0.04-0.27 \mathrm{mg} / 1$ gibi oldukça düşüktür. Florür'ün kaynağı olarak bilinen ve oldukça düşük çözünürlügü olan florit $\left(\mathrm{CaF}_{2}\right)$ hem sedimanter hem de magmatik kayaçlarda bulunur. İnceleme alanında yüzeyleme veren tüf gibi piroklastik kayaçlar da florür için kaynak oluşturur, ancak yüksek pH ve düşük $\mathrm{Ca}^{+2}$ değerlerinde yüksek $\mathrm{F}$ derişimleri görülmektedir (Hem, 1970). Ayrıca yeraltı sularındaki florür derişiminin yağışın potansiyel buharlaşmaya oranına göre belirlenen iklim türü ile ilişkili olduğu belirtilmiştir (Brant vd., 2004). Nemli iklim özelliğine sahip havzada (Gültekin vd., 2005) yer alan kaynakların $\mathrm{pH}$ değerinin düşük, $\mathrm{Ca}^{+2}$ derişiminin yüksek olması sulardaki $\mathrm{F}$ değerlerinin düşük olmasına neden olmuştur.

Sularda ölçülen iz element değerleri genel olarak düşüktür. Kaynaklarda gözlenen en yüksek değere sahip iz element $\mathrm{Sr}$ (0.17113$1.65287 \mathrm{mg} / \mathrm{l})$, ikinci sirada ise Ba $(0.00309$ $0.48995 \mathrm{mg} / \mathrm{l})$ elementidir. Ba, doğada normal sularda daha düşük konsantrasyonlarda (0.043 $\mathrm{mg} / \mathrm{l})$ (Hem, 1970), doğal mineralli sularda ise daha yüksek değerlerde $(0.16 \mathrm{mg} / \mathrm{l})$ (Garboś ve Swiecicka, 2013), en yüksek değerde ise petrol sahalarındaki tuzlu sularda $(650 \mathrm{mg} / \mathrm{l})$ (Collins, 1975) gözlenmiştir. Karbonatlı kayaçlarda az miktarda bulunan Sr ve Ba kimyasal özellikleri $\mathrm{Ca}^{+2}$ ile benzer olup, granit siyenit gibi magmatik kayaçlardaki potasyum ve kalsiyum ile yer değiştirebilirler (Rankama ve Sahama, 1950). Sularda Cr (0.0267- 0.0625 mg/l), Br (0.024$0.046 \mathrm{mg} / \mathrm{l})$ ve B (0.014- $0.037 \mathrm{mg} / \mathrm{l})$ elementleri daha düşük değerlerde bulunur. Çözeltilerde iki değerlikli baskın türler olan $\mathrm{Cu}, \mathrm{Zn}$ ve $\mathrm{Cd}$, incelenen kaynaklarda düşük değerlerdedir. Bunlar ve benzeri metalik element içeren minerallerin çözünürlükleri indirgeyici şartlar altında ve asidik koşullarda daha yüksektir.
Metalik elementler yüksek pH'larda (örğ. $\mathrm{pH}>8$ ) ve oksik koşullarda oksit ve hidroksit mineralleri şeklinde çökelme eğilimindedir. Ortamda indirgeyici sülfür türleri olduğunda $\mathrm{Cu}$ ve $\mathrm{Pb}$ içeren minerallerin çözünürlüğ̈̈ indirgeyici koşullarda, yükseltgeyici koşullara göre daha düşüktür (Hem, 1970). Doğal sularda, $\mathrm{Zn}$ cevherleşmelerinin bulunmadığ alanlarda $\mathrm{Zn}$ konsantrasyonun genellikle 10 ppb'nin altında, $\mathrm{Cd}$ konsantrasyonunun oldukça düşük (Hem, 1970) olduğu belirtilmiştir. Lokal yeraltı suyu sistemlerini temsil eden kaynak sularında eğilim oksijen tüketimine ve dolayısıly indirgeyici (redüksiyon) koşullara doğru olduğundan $\mathrm{Cu}$, $\mathrm{Zn}, \mathrm{Pb}$ ve $\mathrm{Cd}$ elementlerini içeren minerallerin çözünürlükleri düşüktür.

Yeraltı sularının kimyasal gelişiminde içerisinde bulunduğu jeolojik birimi oluşturan minerallerin çözünürlüğü ve açığa çıkan elementlerin jeokimyasal hareketliliği önemlidir. Kaynak sularının iz element içerikleri ile kayaçların iz element içerikleri karşılaştırıldığında indirgeyici koşullarda hareketli olan $\mathrm{Ba}$ ve $\mathrm{Sr}$ değerlerinin sularda da kayaçlarda olduğu gibi yüksek değerlerde olduğu görülmektedir (Şekil 6). Sulardaki içeriği kayaçlardaki derişimleri ile paralellik gösteren $\mathrm{Zn}$ indirgen ortamlarda hareketsiz olmasina rağmen karbonatlı ortamlarda hareketlidir. $\mathrm{Ni}, \mathrm{Cu}, \mathrm{As}, \mathrm{Se}, \mathrm{Mo}, \mathrm{Cd}, \mathrm{Sn}, \mathrm{Sb}, \mathrm{Hf}$, Ta ve Th gibi hareketsiz olan elementler kayaçtaki bileşimlerine paralel derişim göstermektedir. Co, $\mathrm{Zr}, \mathrm{Nb}$ ve $\mathrm{Tl}$ gibi elementlerin kayaçlardakinin aksine sulardaki derişimleri düşüktür. Hem yükseltgeyici, hem de indirgeyici şartlarda hareketli olan Br kayaçlardakinin aksine sularda yüksek derişimlerde bulunmaktadır. 


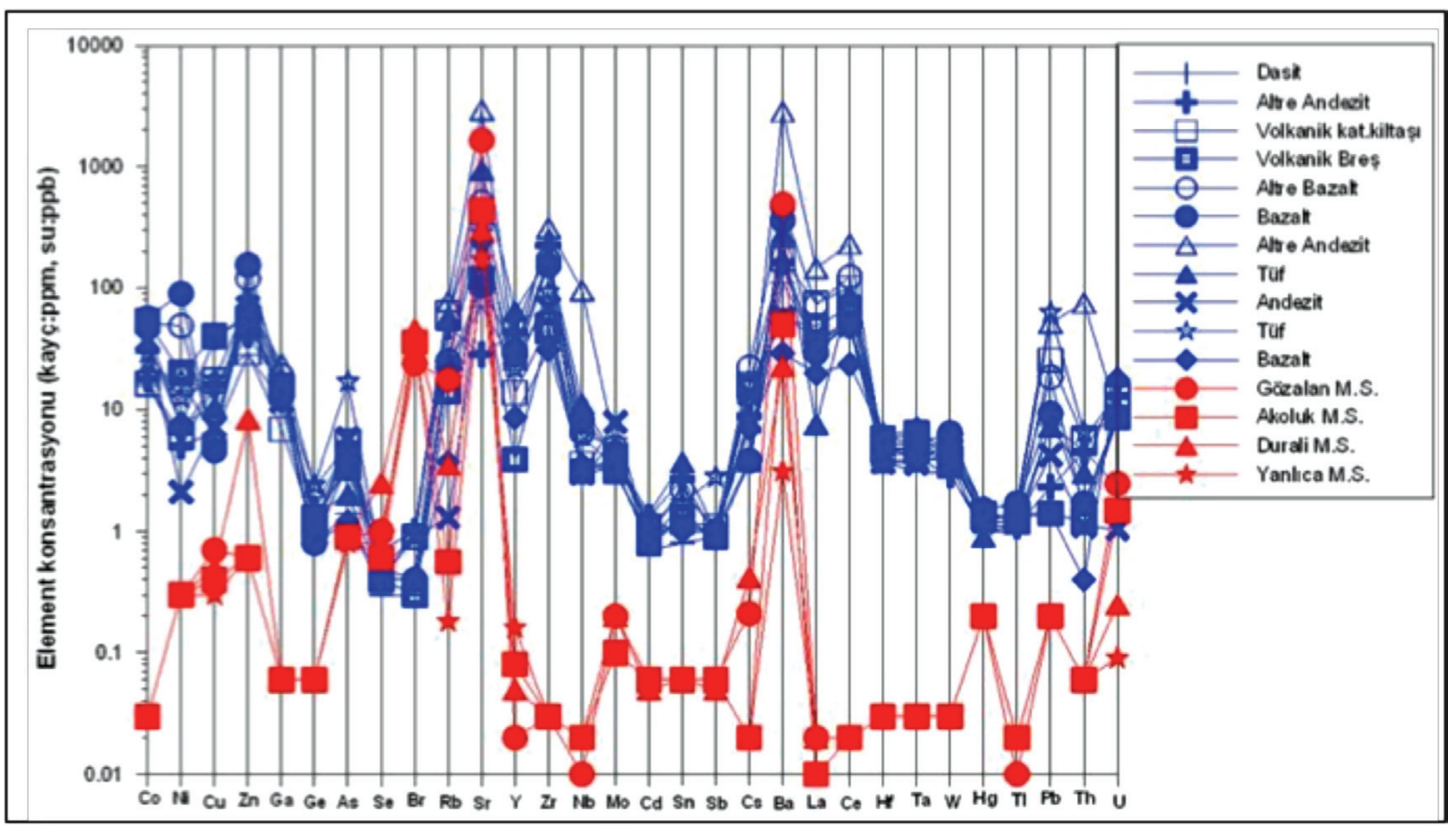

Şekil 6. İncelenen kaynak sularında (ppb) ve çevre kayaçlarında (ppm) iz element konsantrasyonları.

Figure 6. The trace element concentration in the studied spring waters (ppb) and country rocks (ppm).

\section{SONUÇLAR VE ÖNERÍLER}

Yağışlı bir iklime sahip olan çalışma alanı ve çevresinde sürekli akışa sahip, normal sulara göre daha yüksek iyon içeren kaynaklarda su tipi Ca$\mathrm{HCO}_{3}^{-}$'tür. Toplam iyon miktarları y1l boyunca değişiklik göstermeyen bu kaynak sularındaki majör iyonların mek/l değerlerine göre bolluk sıralamaları birbirine oldukça benzerdir. Genel olarak düşük konsantrasyonlarda olan iz elementler açısından da kaynak suları birbirlerine benzerlik gösterir. Havzada topoğrafik eğimin yüksek ve çok sayıda yan vadilerin olması havzaya düşen yağışın sı̆̆ dolaşımlarla kısa sürede vadi tabanlarına yakın kotlardan kaynaklar şeklinde boşalmasına neden olmaktadır. Kaynakların $\delta^{18} \mathrm{O}$ ve $\delta^{2} \mathrm{H}$ izotop değerleri de bunu destekler niteliktedir. Kaynakların beslenme havzalarında kireçtaşı, killi kireçtaşı ve marn arakatkıları içeren bazalt, andezit ve piroklastik kayaçlar yüzeylenir. Kloritleşme ve epidotlaşma şeklinde yoğun ayrışmanın gözlendiği volkanik kayaçlarda birincil olarak plajioklas, piroksen, biyotit ve hornblend mineralleri, ikincil olarak kuvars ve kalsit mineralleri tespit edilmiştir.

Kaynak sularının kimyasal bileşiminde silikat ayrışması, karbonatlı minerallerin çözünmesi ve iyon değişimi süreçlerinin etkili olduğu belirlenmiştir. Silikatlı minerallerin ayrışması kaynak sularının kimyası üzerindeki ana kontrol olarak yorumlanmıştır. Kayaçların ayrışmış türlerinde yüksek derişimlerde gözlenen ve indirgeyici ortam koşullarında hareketli olan iz elementler sularda da yüksek değerlerde bulunmaktadır.

Kayaç ayrışmasının etkili olduğu Değirmendere Havzası'nda volkanik kayaçların çatlak ve fay zonlarından yüzeye çıkan Gözalan, Akoluk, Durali ve Yanlıca kaynak suları normal yeraltı sularına göre daha fazla iyon içerirler. Bu iyon içerikleri ile bu tür kaynaklar Doğal Mineralli Sular Hakkındaki Yönetmelik (2004)'e göre «düşük mineralli su» ve «mineralli 
Tahmasebzadeh Bastam, Gültekin

su» sınıfinda değerlendirilmektedir. $\mathrm{Bu}$ tür suların iz element konsantrasyonları içilebilme özelliklerini etkilemektedir. İncelenen kaynak sularının $\mathrm{Br}(0.036-0.070 \mathrm{mg} / \mathrm{l})$ ve $\mathrm{Cr}(0.0625$ $\mathrm{mg} / \mathrm{l})$ değerleri Doğal Mineralli Sular Hakkındaki Yönetmelik (2004)'te önerilen sinır değerleri aşmaktadır. Yönetmelikte verilen sınır değerleri aşmamasına rağmen $\mathrm{Sr}(0.17113-1.65287 \mathrm{mg} / \mathrm{l})$ ve $\mathrm{Ba}(0.00309-0.48995 \mathrm{mg} / \mathrm{l})$ konsantrasyonlar1 da normal sulara göre daha yüksektir. Çözünmüş madde miktarı normal sular göre daha yüksek fakat mineralli sulara göre daha düşük olan bu kaynak suları, yan kayaçlardaki ayrışmaya bağlı olarak su-kayaç etkileşiminin gözlendiği sı̆ dolaşıma sahip yeraltı sularıdır. Yerleşim alanı içerisinde ve yoğun tarım faaliyetlerinin etki alanında bulunan bu kaynaklar ilaç, gübre ve evsel atıklar tarafından da kirlenmeye karşı korunmasızdır. Kaynakların hepsinde $\mathrm{NO}_{3}$ ve $\mathrm{NH}_{4}$ değerleri normal sulara göre daha yüksek, Durali kaynağında ise $\mathrm{NO}_{3}$ konsantrasyonu Doğal Mineralli Sular Hakkındaki Yönetmelik (2004)'te önerilen değeri aşmaktadır. Dolaysıyla bu tür kaynakların içilebilme özelliklerini etkileyen parametreler açısından bir süre takip edilip yönetmeliklerde verilen değerleri aşan parametrelerin olması durumda da kaynakların kullanımlarının engellenmesi yöre halkı sağlı̆̆ açısından önemlidir.

\section{KAYNAKLAR}

Alkan, A., Serdar, S., Fidan, D., Akbaş, U., Zengin, B., Kılı̨̧, M.B., 2013. Physico-chemical characteristics and nutrient levels of the eastern black sea rivers. Turkish Journal of Fisheries and Aquatic Sciences, 13, 847-859.

Appelo, C. A. J., Postma, D., 1994. Geochemistry, groundwater and pollution. Rotterdam: Balkema, $536 \mathrm{p}$.

Aydın, F., 2003. Değirmendere vadisi (TrabzonEsiroğlu, KD- Türkiye) volkanitlerinin mineral kimyası, petrolojisi ve petrojenezi. Karadeniz Teknik Üniversitesi Fen Bilimleri Enstitüsü, Trabzon. Doktora Tezi, 232 s. (yayımlanmamış).

Brunt, R., Vasak, L., Griffioen, J., 2004. Fluoride in groundwater: probability of occurrence of excessive concentration on global scale. International Groundwater Resources Assessment Centre (Igrac) Report nr: Sp 2004-2.

Collins, A. J., 1975. Geochemistry of oil field waters: New York, Elsevier Scientific Pub. Co. 496 p.

Craig, H., 1961. Isotopic variations in meteoric water. Science, 133, 1702-1703.

Davraz, A., 2003. Kaya- su etkileşimi üzerine bir çalışma, Keçiborlu- Değirmendere kaynağı (Isparta). Süleyman Demirel Üniversitesi, Fen Bilimleri Enstitüsü Dergisi, 7 (2), 327-335.

Drever, J. I., 1997. The geochemistry of natural waters. Third edition. New Jersey: PrenticeHall. Inc. 436 p.

Ekmekçi, M., Gültekin, F., 2015. Doğu Karadeniz bölümü suları çevresel duraylı izotop içeriğinin değerlendirilmesi. MÜHJEO'2015 Ulusal Mühendislik Jeolojisi Sempozyumu, (Editörler: Ulusay, Ekmekçi, Ersoy ve Fırat Ersoy), Trabzon, 459-466.

Freeze, R. A., Cherry, J. A., 1979. Groundwater. Englewood Cliffs: Prentice-Hall. Inc. 562 p.

Garbos, S., Swiecicka, D., 2013. Determination of barium in natural waters by ICP-OES technique. Part II: Assessment of human exposure to barium in bottled mineral and spring waters produced in Poland. Roczniki Panstwowego Zakladu Higieny. 64, (2), 91-6.

Garrels, R. M., Mackenzie, F.T., 1971. Evolution of sedimentary rocks. New York: WW Norton. 413 p.

Gibbs, R.J., 1970. Mechanisms controlling world water chemistry. Science Journal, 170,795-840.

Gültekin, F., Dilek, R., Firat Ersoy, A., Ersoy, H., 2005. Aşağı Değirmendere (Trabzon) havzası'ndaki suların kalitesi. Jeoloji Mühendisliği Dergisi, 29 (1), 21-35.

Gültekin, F., Fırat Ersoy, A., Hatipoğlu, E., 2010. Trabzon ili $\mathrm{CO}_{2}$ 'ce zengin kaynak sularında su- 
kayaç ilişkisi, IV. Ulusal Jeokimya Sempozyumu, (Editör: Şaşmaz), Elazığ, 113.

Güven, İ. H., 1993. Doğu Pontidlerin jeolojisi ve 1/250.000 ölçekli kompilasyonu. MTA Yayınları, Ankara.

Hamzaoui-Azaza, F., Ketata, M., Bouhlila, R., Gueddari, M., Riberio, L., 2011. Hydrogeochemical characteristics and assessment of drinking water quality in Zeuss-Koutine aquifer, southeastern Tunisia. Environmental Monitoring and Assessment, 174, 283-298.

Hem, J. D., 1970. Study and interpretation of the chemical characteristics of natural water. Geological Survey (U.S.), Water-supply paper, Second Edition, 363 p.

Hounslow, A. W., 1995. Water quality data: analysis and interpretation. Lewis Publishers, $416 \mathrm{p}$.

Kara, İ., 1997. Termal ve mineralli sular envanteri Trabzon, MTA Genel Müdürlüğü, Enerji Hammadde Etüt ve Arama Dairesi Başkanlığı, Ankara, (yayımlanmamış).

Korkmaz, S., 1993. Tonya-Düzköy (GB Trabzon) yöresinin stratigrafisi. Türkiye Jeoloji Bülteni, 36, $151-158$.

Langmuir, D., 1997. Aqueous environmental geochemistry. Prentice Hall, Inc., 601p.

MGM, 2015. Meteoroloji Genel Müdürlüğü, İllerimize ait istatistik verileri, $20 \mathrm{Kasım,} \mathrm{2015,}$ https://www.mgm.gov.tr/veridegerlendirme/ilve-ilceler-istatistik.
Parkhurst, D. L., Appelo, C. A. J., 1999. User's guide to PHREEQC (version 2): A computer program for speciation, batch reaction, one dimensional transport, and inverse geochemical calculations. U.S. Geological Survey Water-Resources Investigations Report. pp. 99-4259.

Rankama, K., Sahama, T. H. G., 1950. Geochemistry, The university of Chicago Pres, Chicago and London, 912 p.

Sami, K., 1992. Recharge mechanisms and geochemical processes in a semi-arid sedimentary basin, Eastern Cape, South Africa. Journal of Hydrology (Amsterdam), 139, 27-48.

Scislewski, A., Zuddas, P., 2010. Estimation of reactive mineral surface area during water-rock interaction using fluid chemical data. Geochimica et Cosmochimica Acta, 74, 6996-7007.

Schoeller, H., 1965. Qualitative evaluation of groundwater resources. In Methods and techniques of groundwater investigations and development, UNESCO, 54-83.

Schoeller, H., 1967. Geochemistry of groundwateran international guide for research and practice (Chap.). UNESCO, 15, 1-18.

T.C. Resmi Gazete, 2004. Doğal mineralli sular hakkında yönetmelik, 25657.

Zhu, C., 2005. In situ feldspar dissolution rates in an aquifer. Geochimica et Cosmochimica Acta, 69 (6), 1435-1453. 
